\title{
Investigation on mechanical properties and wear behavior of Cu-alloyed austempered gray cast iron (AGI)
}

\author{
T SARKAR $^{1, *}$ and G SUTRADHAR ${ }^{2}$ \\ ${ }^{1}$ School of Automotive Engineering, Jadavpur University, Kolkata 700032, India \\ ${ }^{2}$ Department of Mechanical Engineering, Jadavpur University, Kolkata 700032, India \\ e-mail: tannybesu@gmail.com; cast_1963@rediffmail.com
}

MS received 20 May 2016; revised 3 July 2018; accepted 5 July 2018; published online 20 August 2018

\begin{abstract}
The aim of this investigation is to assess the influence of austempering heat treatment on microstructure, mechanical properties, and wear behavior of copper alloyed AGI. Tensile and wear test samples are prepared from as-cast gray iron. Initially, samples are austenitized and then isothermally austempered at six different temperatures for the constant time period. The resulting microstructures are evaluated and characterized by means of a light microscope, scanning electron microscope (SEM) and X-ray diffraction analysis. The wear test is carried out using a "block-on-roller" type multi-tribotester machine. The mechanical properties and wear behavior of the AGI samples are also determined and discussed systematically. Results showed that the mechanical and wear properties of AGI are significantly enhanced in comparison with as-cast gray iron. The wear behavior of AGI samples may be correlated with microstructure and mechanical properties. The hardness, tensile strength, elongation and volume fraction of austenite act as independently in influencing the wear behavior.
\end{abstract}

Keywords. Austempered gray cast iron (AGI); austempering temperature; microstructure; mechanical properties; wear.

\section{Introduction}

Gray cast iron is a widely used engineering material. From simple domestic cooking pans, pump housing and sewing machine bodies to sophisticated cylinder blocks and cylinder heads of high duty trucks. Its range of applications is diverse and large. The reason behind the popularity of gray cast iron is due to its unique properties like relatively low melting temperature, excellent castability, high damping capacity and good thermal conductivity $[1,2]$.

The physical and mechanical properties of gray cast irons have been determined by its microstructure which consists of flakes of graphite distributed over the matrix of pearlite or ferrite or ferrite + pearlite [3]. Austempering heat treatment process is applied to gray cast iron to produce austempered gray cast iron (AGI) with much improved mechanical properties [4, 5]. Austempering develops an ausferrite (ferrite and high carbon and stable austenite) microstructure. This unique microstructure (ausferrite) contributes standard mechanical properties to austempered gray cast iron (AGI) [4-7]. Therefore, AGI finds applications in the automobile industry as gears, pistons, cylinder liners, etc. and also in agricultural equipment $[4,8]$. The austempering process consists of initial austenitizing

*For correspondence treatment in the temperature range of $871-982^{\circ} \mathrm{C}$ $\left(1600-1800^{\circ} \mathrm{F}\right)$ followed by quenching to an intermediate temperature range of $260-385^{\circ} \mathrm{C} \quad\left(500-725^{\circ} \mathrm{F}\right)$ and isothermal holding for sufficient time [8,9]. It is possible to obtain a wide range of properties in AGI by adjusting the austempering heat treatment cycle, i.e., austenitizing temperature, austempering temperature and time $[4,5]$.

Although, several research investigations on mechanical properties [4-8] and wear behavior [10-14] of austempered gray cast iron (AGI) have been carried out in the past, structured information on the effects of different austempering process parameters like alloy design, austenitizing temperature, austempering temperature and time of AGI is still lacking. Moreover, in the Indian context, cupola melting is the predominant mode of melting gray cast irons of wide section size ranges. Such cast iron melts usually have relatively high phosphorus contents (around $0.2 \% \mathrm{P}$ ).

Therefore, an approach is developed in this study to establish a correlation of microstructure with mechanical and wear properties of AGI. In this study, the influence of austempering temperature on microstructure and eventually on mechanical and wear properties of $\mathrm{Cu}$-alloyed AGI is carried out. It is expected that this study may immensely benefit the academicians as well as industries working in this area as AGI has much potential in enormous 


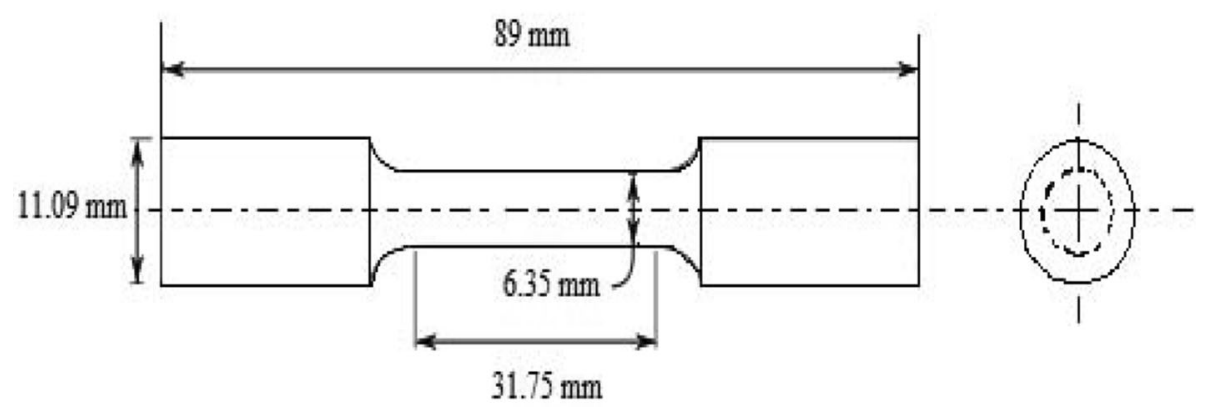

Figure 1. Schematic of tensile test bar (ASTM-E8).

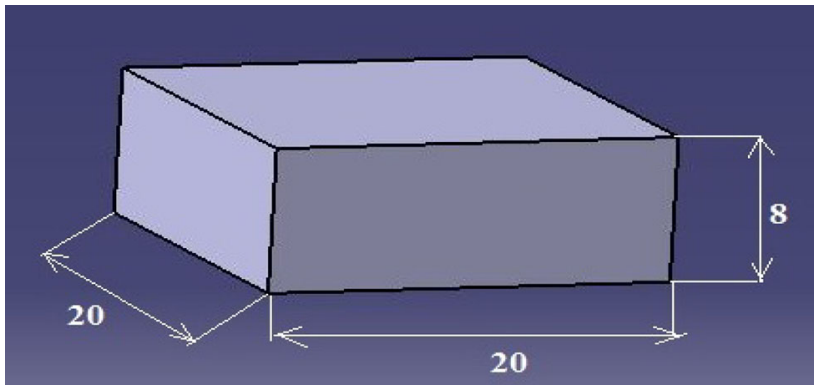

Figure 2. Schematic of wear test specimen $(20 \times 20 \times 8 \mathrm{~mm})$.

applications particularly in automobile industry such as cylinder liner, crank shaft, gear manufacturing, etc.

\section{Experimental procedure}

Gray cast iron keel blocks having a chemical composition of $3.46 \mathrm{C} ; 2.27 \mathrm{Si} ; 0.53 \mathrm{Mn} ; 0.5 \mathrm{Cu} ; 0.19 \mathrm{P} ; 0.1 \mathrm{~S}$ (wt.\%) are cast in a commercial gray iron foundry from cupola melt. The melt is poured at about $1420^{\circ} \mathrm{C}$ into standard $30 \mathrm{~mm} \mathrm{Y}$ block molds (ASTM A-395). Sound castings are produced. ASTM E-8 standard [15] tensile test specimens (figure 1) and standard wear test specimens $(20 \times 20 \times 8 \mathrm{~mm})$ (figure 2) are machined from the coupons of the $Y$ block castings. Initially experiments have been conducted at $927^{\circ} \mathrm{C}\left(1700^{\circ} \mathrm{F}\right)$ of austenitizing temperature and rapidly transferred to a salt bath $\left(53 \% \mathrm{KNO}_{3}, 40 \% \mathrm{NaNO}_{2}\right.$ and $\left.7 \% \mathrm{NaNO}_{3}\right)$ at different austempering temperatures such as $260^{\circ} \mathrm{C}\left(500^{\circ} \mathrm{F}\right), 285^{\circ} \mathrm{C}\left(545^{\circ} \mathrm{F}\right) 310^{\circ} \mathrm{C}\left(590^{\circ} \mathrm{F}\right), 335^{\circ} \mathrm{C}$ $\left(635^{\circ} \mathrm{F}\right), 360^{\circ} \mathrm{C}\left(680^{\circ} \mathrm{F}\right)$ and $385^{\circ} \mathrm{C}\left(725^{\circ} \mathrm{F}\right)$ for $1 \mathrm{~h}$ and then air cooled at room temperature. The schematic diagram for austempering heat treatment process is shown in figure 3(a) and (b).

For microstructural examination, standard metallographic preparation techniques such as mechanical grinding, polishing followed by Nital etching were carried out. Metallographic samples are examined in a light microscope (Leica) and scanning electron microscope (SEM) (JSM 6360). X-Ray diffraction (XRD) analyses were performed to calculate the relative proportions of austenite content, following the procedure of Dasgupta et al [16]. XRD analysis has been performed (Diffractometer, Rigaku, Ultima III) using monochromatic copper $\mathrm{Fe}-\mathrm{K} \alpha$ radiation

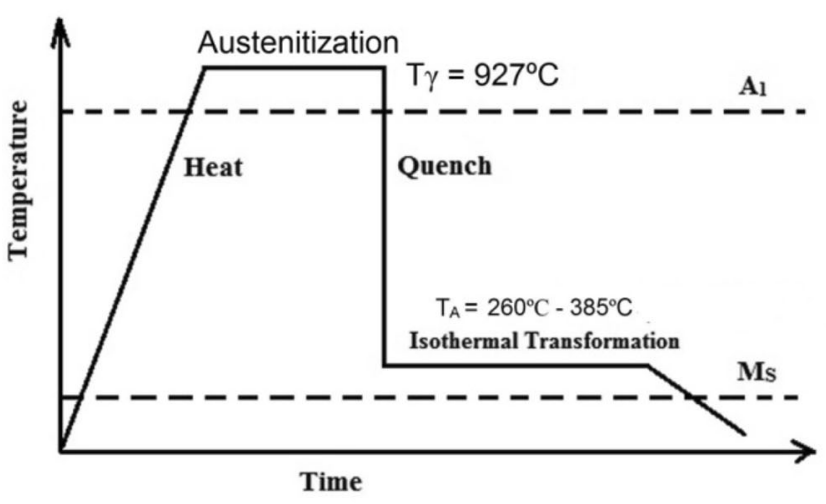

(a)

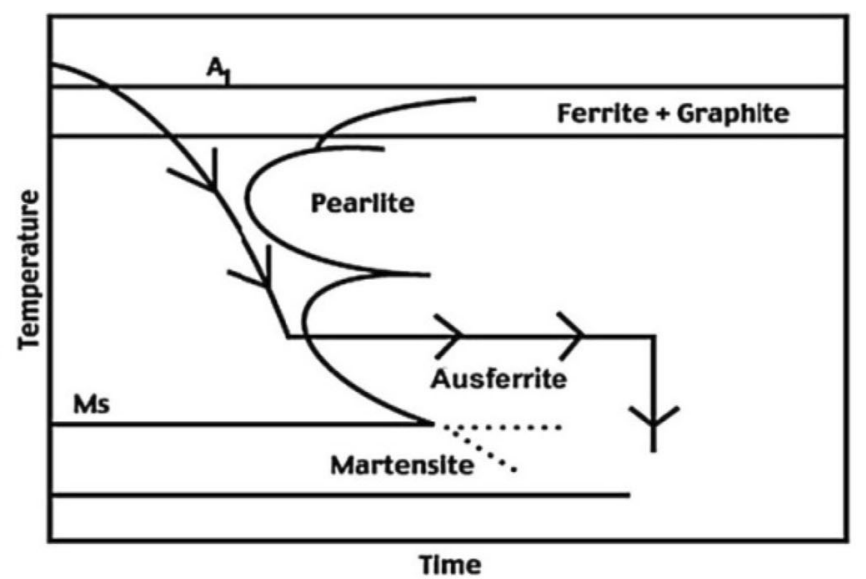

(b)

Figure 3. (a, b). Schematic of conventional austempering process. 
$(1.54059 \AA)$ at $40 \mathrm{kV}$ and $30 \mathrm{~mA}$. The scan angular (20) ranged from $30^{\circ}$ to $90^{\circ}$ at a scanning speed of $1 \%$ minute. The profiles are analyzed using Jade 7 software to obtain peak positions and integrated intensities of (111), (220) and (311) planes of FCC austenite and (110), (200) and (211) planes of BCC ferrite. The percentage of carbon content in austenite $\left(\mathrm{C}_{\gamma}\right)$ is calculated using the equation $\mathrm{C}_{\gamma}=\left(\alpha_{\gamma}-\right.$ $3.548) / 0.044$, where $\alpha_{\gamma}$ is the lattice parameter calculated from the angular position of the austenite peak [17]. The phase constituents of ferrite and graphite content are analyzed using an image analyzer in the optical microscope, following the procedure of Vadiraj et al [12].

The hardness of the as-cast and AGI samples is measured using a Brinell hardness tester fitted with $5 \mathrm{~mm}$ ball under a load of $750 \mathrm{~kg}$. Dwell time is taken as $10 \mathrm{~s}$. The tensile tests are carried out at room temperature as per ASTM-E8 Standard [15] with a crosshead speed of $1 \mathrm{~mm} / \mathrm{min}$ using a computerized Instron-8801 electromechanical testing machine. The tensile strength and percentage of elongation values have been calculated. Wear test has been carried out on a block-on-roller (make Ducom, India) type machine at a linear speed of $1.86 \mathrm{~m} / \mathrm{s}$ under $75 \mathrm{~N}$ load at room temperature. A rotating roller disc of hardened steel, EN31 of hardness RC 62 acted as a counter body. The tests are conducted for $30 \mathrm{~min}$. The wear values of as-cast and AGI samples have been determined. The worn surfaces of the test specimens are also examined in a SEM in order to determine the wear surface characteristics. Four specimens are tested for each heat treatment condition and the average values of them are considered. Mechanical and wear properties of as-cast gray iron is shown in table 1 .

\section{Results and discussion}

\subsection{Microstructure}

The microstructure of the as-cast material (figure 4(a) and (b)) shows a high concentration of randomly oriented and uniformly dispersed graphite flakes. The matrix is predominantly (over 70\%) pearlitic in nature. The graphite flakes act as stress raisers and thus embrittle the metal.

Figure 5(a)-(f) and figure 6(a)-(f) show the optical and SEM microstructures of the austempered samples and give a qualitative picture of microstructural evolution. After austempering, the microstructure primarily consists of major ferrite phase (dark) and secondary austenite phase (white) with graphite flakes dispersed within it. This is the typical ausferrite (ferrite and high carbon and stable austenite) microstructure. As the austempering temperature is increased, both the ferrite and austenite phases have been to be coarsening significantly. At lower austempering temperatures (e.g., $260^{\circ} \mathrm{C}, 285^{\circ} \mathrm{C}$ ), the matrix microstructure consists of fine ferrite and austenite. However, at a higher austempering temperatures (e.g., $360^{\circ} \mathrm{C}$ and above), the coarse and feathery ferrite in an overall ausferrite matrix is observed.

Optical microstructures and SEM images present a qualitative picture of the microstructural evolution. Quantitative information is obtained from the $\mathrm{X}$-ray diffraction pattern analysis [16] as shown in figure 7.

The volume fraction of austenite and ferrite as a function of the austempering temperatures is presented in figure 8 . The volume fraction of austenite increases with increasing austempering temperature. On the other hand, the volume

Table 1. Mechanical properties of as-cast gray iron.

\begin{tabular}{lcccc}
\hline Sample condition & Hardness $(\mathrm{BHN})$ & Strength $(\mathrm{MPa})$ & Elongation $(\%)$ & Wear $(\mu \mathrm{m})$ \\
\hline As-cast gray iron & 209 & 172 & 0.6352 \\
\hline
\end{tabular}

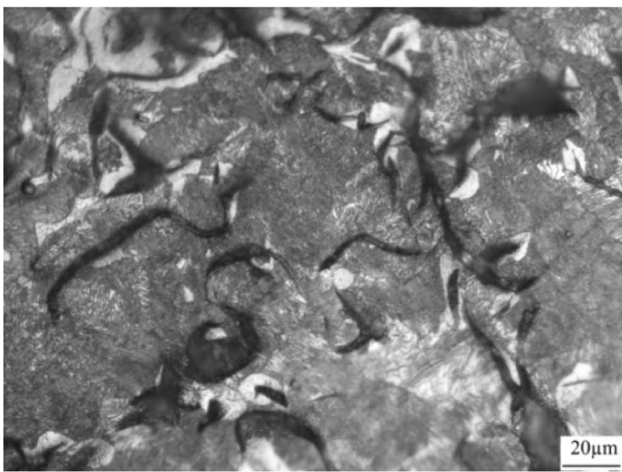

(a)

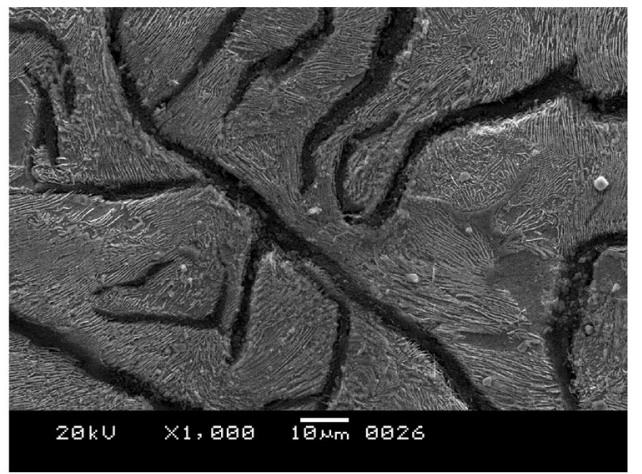

(b)

Figure 4. Micrographs (500X) of an as-cast specimens. (a) Optical micrograph, (b) SEM micrograph. 


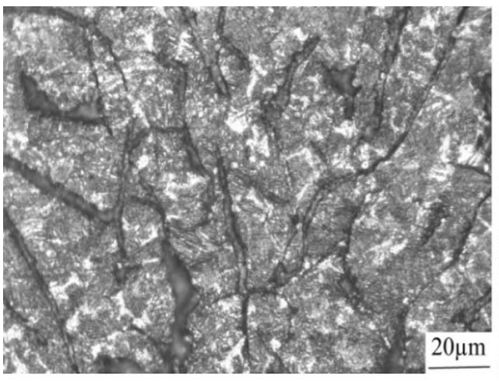

(a)

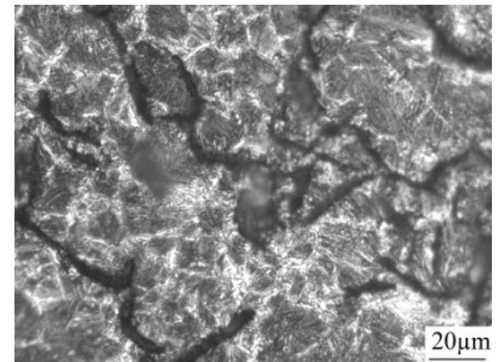

(d)

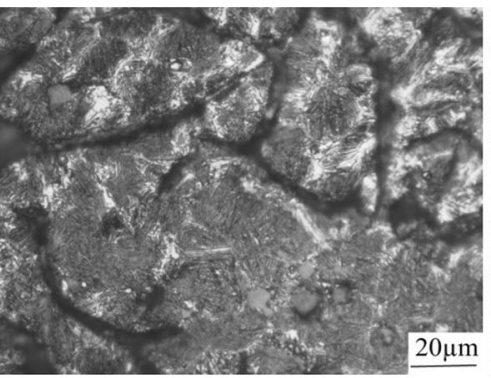

(b)

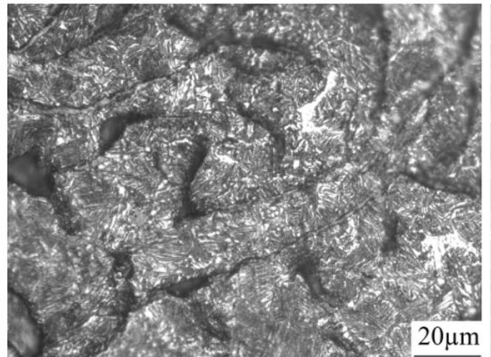

(e)

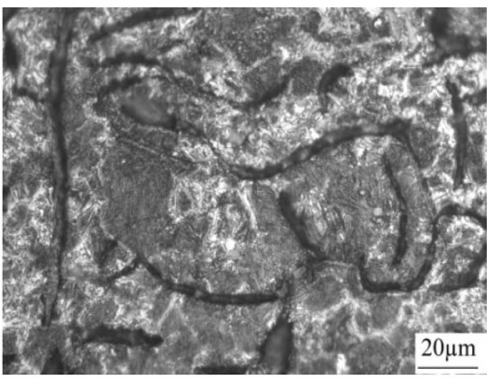

(c)

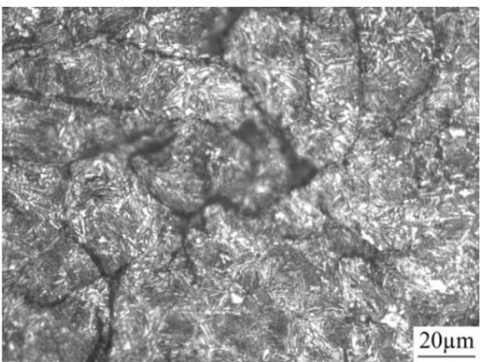

(f)

Figure 5. Optical micrographs (500X) of AGI samples. (a) $260^{\circ} \mathrm{C}$ of austempering, (b) $285^{\circ} \mathrm{C}$ of austempering, (c) $310^{\circ} \mathrm{C}$ of austempering, (d) $335^{\circ} \mathrm{C}$ of austempering, (e) $360^{\circ} \mathrm{C}$ of austempering and (f) $385^{\circ} \mathrm{C}$ of austempering.

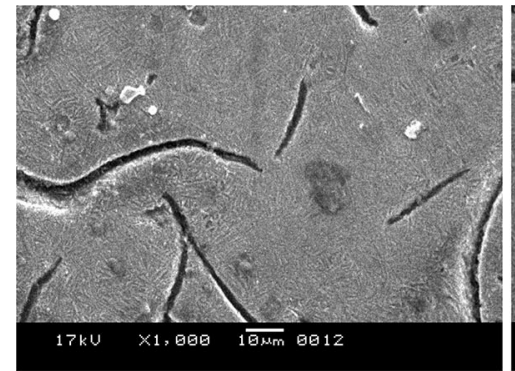

(a)

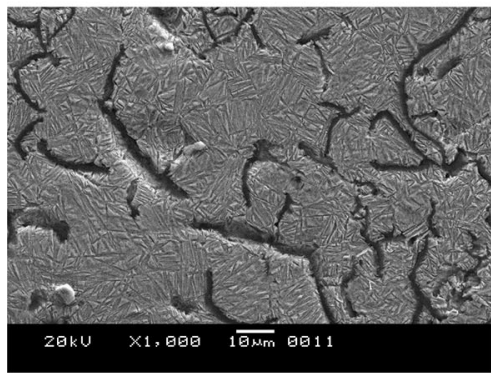

(d)

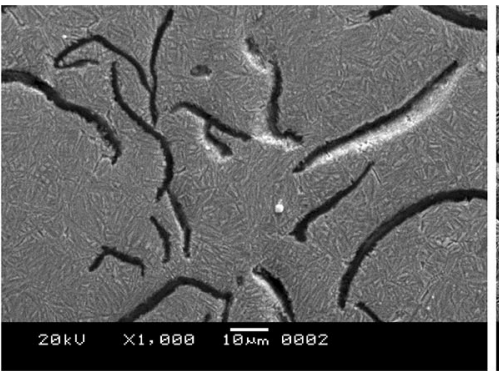

(b)

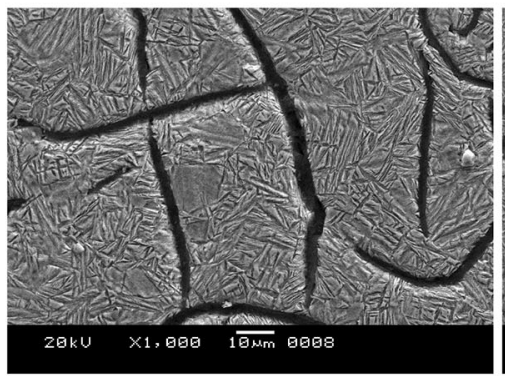

(e)

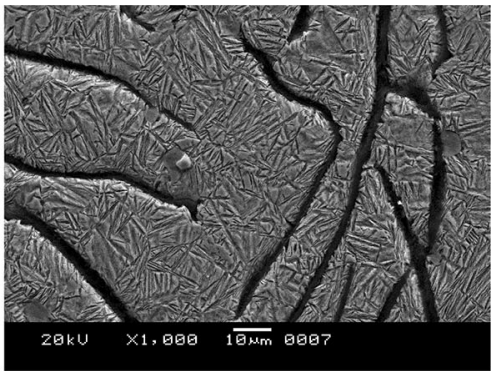

(c)

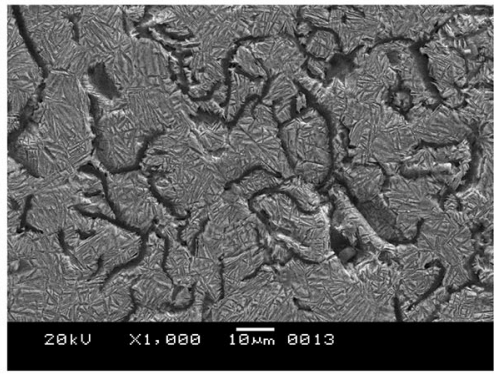

(f)

Figure 6. SEM micrographs of AGI samples. (a) $260^{\circ} \mathrm{C}$ of austempering, (b) $285^{\circ} \mathrm{C}$ of austempering, (c) $310^{\circ} \mathrm{C}$ of austempering, (d) $335^{\circ} \mathrm{C}$ of austempering, (e) $360^{\circ} \mathrm{C}$ of austempering and (f) $385^{\circ} \mathrm{C}$ of austempering.

fraction of ferrite decreases as the austempering temperature increases. However, the austenite content increases from $9.27 \%$ to $24.51 \%$ as the austempering temperature is increased from $260^{\circ} \mathrm{C}$ to $385^{\circ} \mathrm{C}$. On the other hand, the ferrite content decreases from $73.55 \%$ to $56.15 \%$ as the austempering temperature is increased from $260^{\circ} \mathrm{C}$ to $385^{\circ} \mathrm{C}$. During the austempering process, the ferrite forms out of austenite. Since ferrite dissolves very little carbon, the carbon must diffuse out into the surrounding austenite [9, 18]. Accordingly, nucleation depends on the 


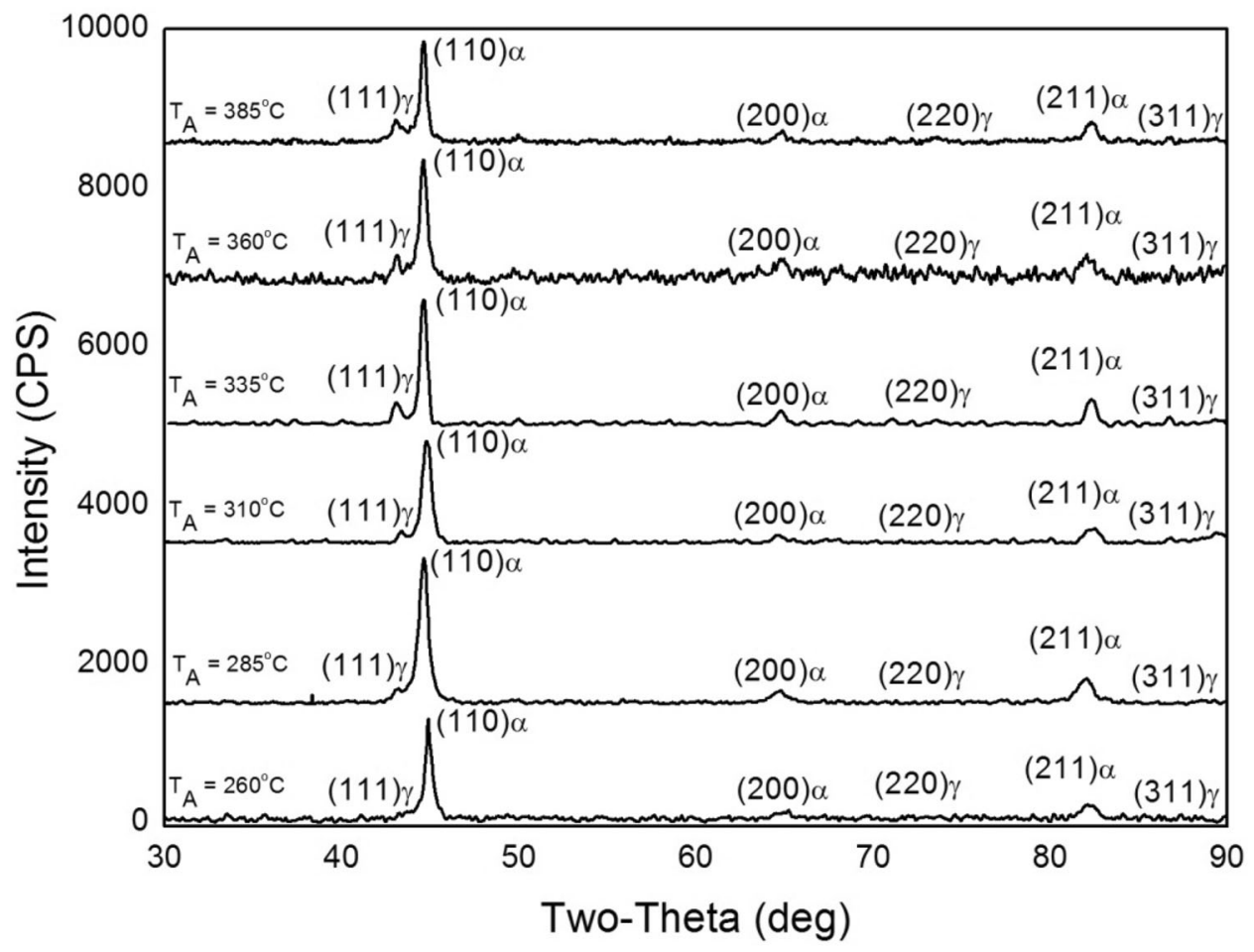

Figure 7. XRD phase analysis of AGI materials, austenitizing at $927^{\circ} \mathrm{C}$ for different austempering temperature at (a) $260^{\circ} \mathrm{C}$ for $1 \mathrm{~h}$, (b) $285^{\circ} \mathrm{C}$ for $1 \mathrm{~h}$, (c) $310^{\circ} \mathrm{C}$ for $1 \mathrm{~h}$, , d) $335^{\circ} \mathrm{C}$ for $1 \mathrm{~h}$, (e) $360^{\circ} \mathrm{C}$ for $1 \mathrm{~h}$ and (f) $385^{\circ} \mathrm{C}$ for $1 \mathrm{~h}$, respectively.
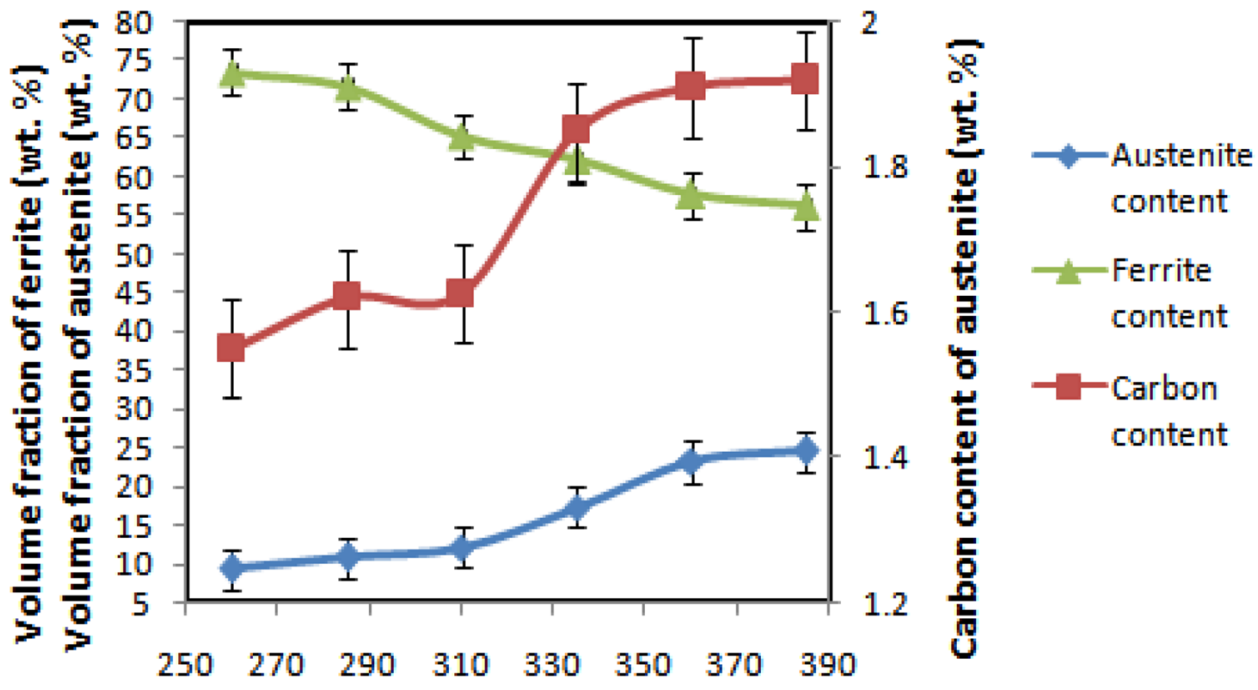

Austempering temperature $\left({ }^{\circ} \mathrm{C}\right)$

Figure 8. Variation of the austenite, ferrite content and carbon content in austenite with austempering temperatures.

supercooling leads to the fact that more ferrite is nucleated as the austempering temperature is lowered. At the same time, due to the lower diffusion rate of carbon at low temperature, the growth rate of ferrite is also reduced. So the ferrite becomes finer in nature $[9,18]$. Thus, at a lower austempering temperature, the austenite volume fraction $\left(X_{\gamma}\right)$ is lower, i.e., the ferrite volume fraction $\left(X_{\alpha}\right)$ is higher, and both austenite and ferrite are finer in nature. However, at a higher austempering temperature, because of the lower supercooling, the rate of nucleation of ferrite is lower, and at the same time, the higher diffusion rate of carbon causes the ferrite to become coarse or feathery in nature $[9,18]$. Thus, at a higher austempering temperature (e.g., $360^{\circ} \mathrm{C}$ and above) a higher volume fraction of austenite is obtained 


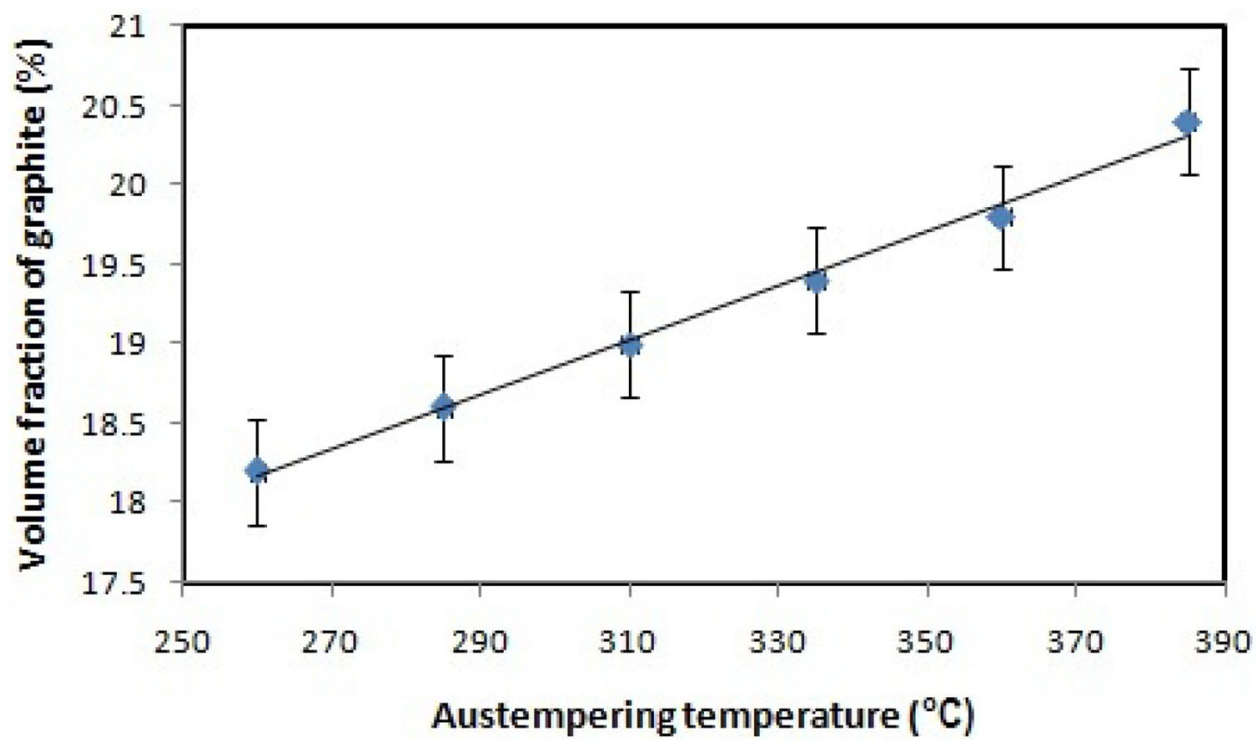

Figure 9. Influence of austempering temperatures on the graphite content.

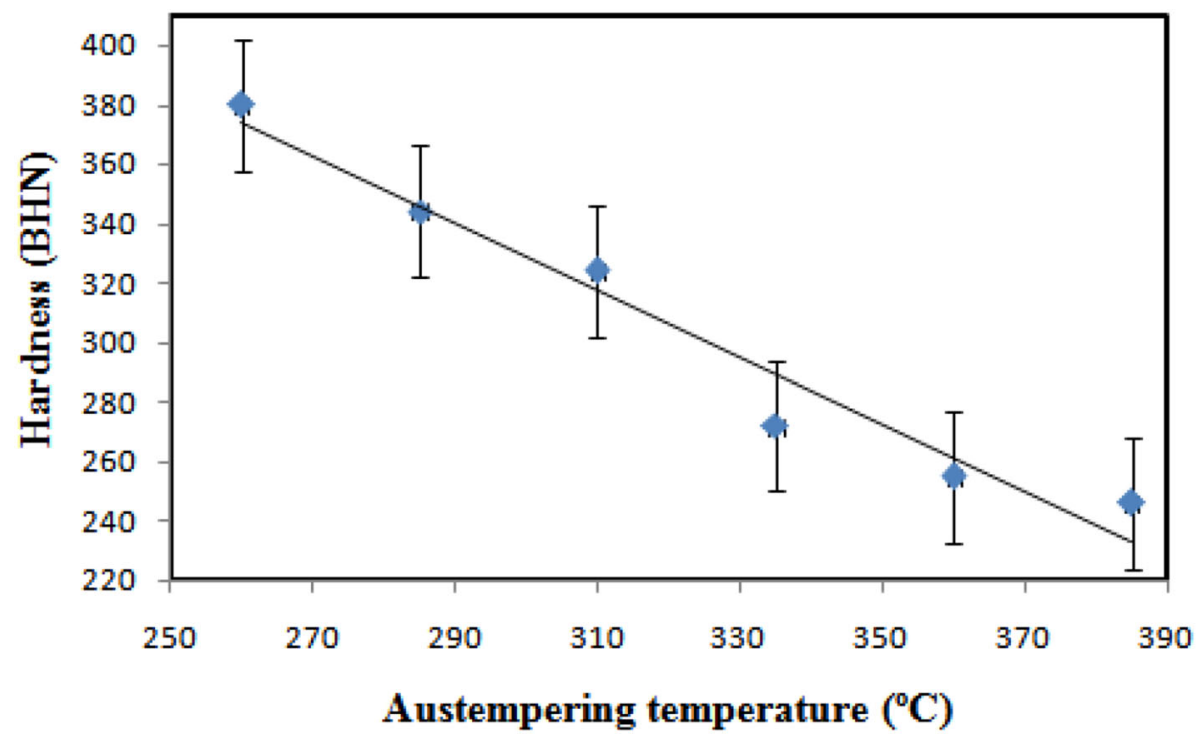

Figure 10. Influence of austempering temperatures on hardness (BHN).

in combination with a lower volume fraction of ferrite. Both the ferrite and austenite become coarse or feathery in nature. Figure 8 is a plot of carbon content of austenite against austempering temperature. It is seen that as the austempering temperature increases, the carbon content of austenite also increases, because of a higher diffusion rate of carbon at a higher temperature $[9,18]$. However, carbon content rises from $1.55 \%$ at $260^{\circ} \mathrm{C}$ to $1.92 \%$ at $385^{\circ} \mathrm{C}$.

Figure 9 is a plot of the volume fraction of graphite against austempering temperature. It shows that the graphite content slightly increases with austempering temperature. For instance, the graphite content increases from $18.2 \%$ at $260^{\circ} \mathrm{C}$ to $20.4 \%$ at $385^{\circ} \mathrm{C}$. Hence, with the increase in austempering temperature, increase diffusivity of carbon which results in the ferrite and austenite are both coarser and feathery in nature. Thus, at a higher temperature, a higher volume fraction of graphite is obtained. Vadiraj et al [12] similarly have determined relative volume fractions of phase in austempered hypereutectic gray cast iron.

\subsection{Mechanical properties}

The hardness variation with austempering temperature is shown in figure 10. Higher hardness is noticed at the lower austempering temperature and vice versa. A maximum hardness of $380 \mathrm{BHN}$ is recorded at an austempering 


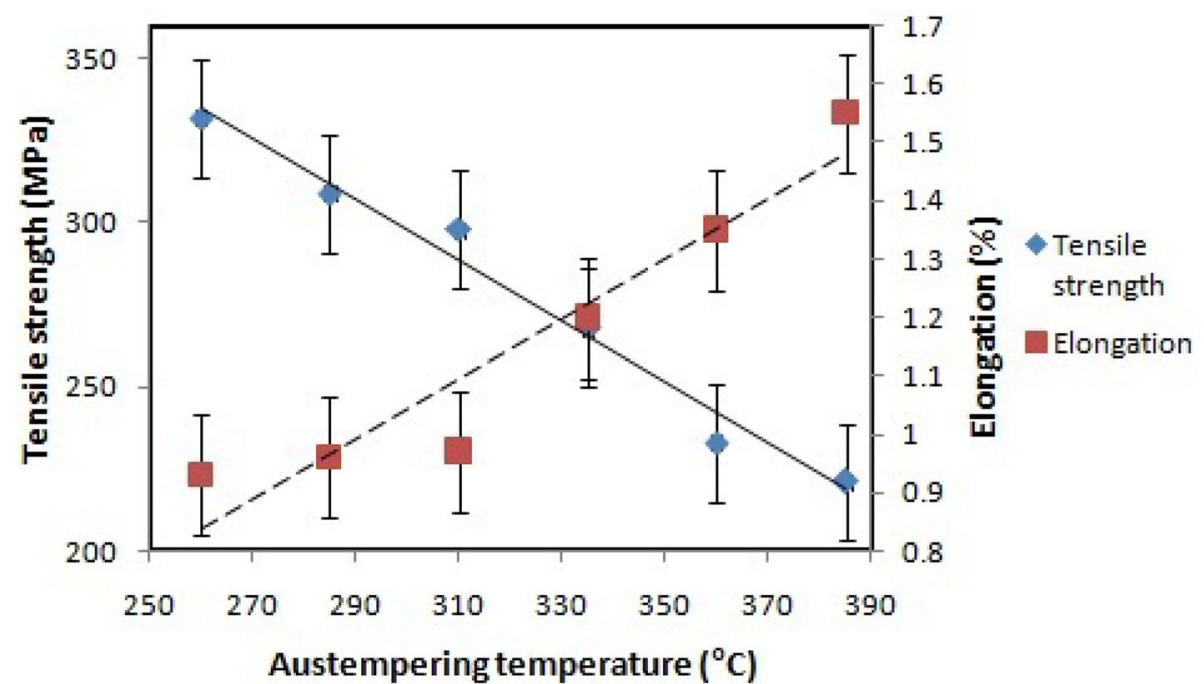

Figure 11. Variation of tensile properties with austempering temperatures.

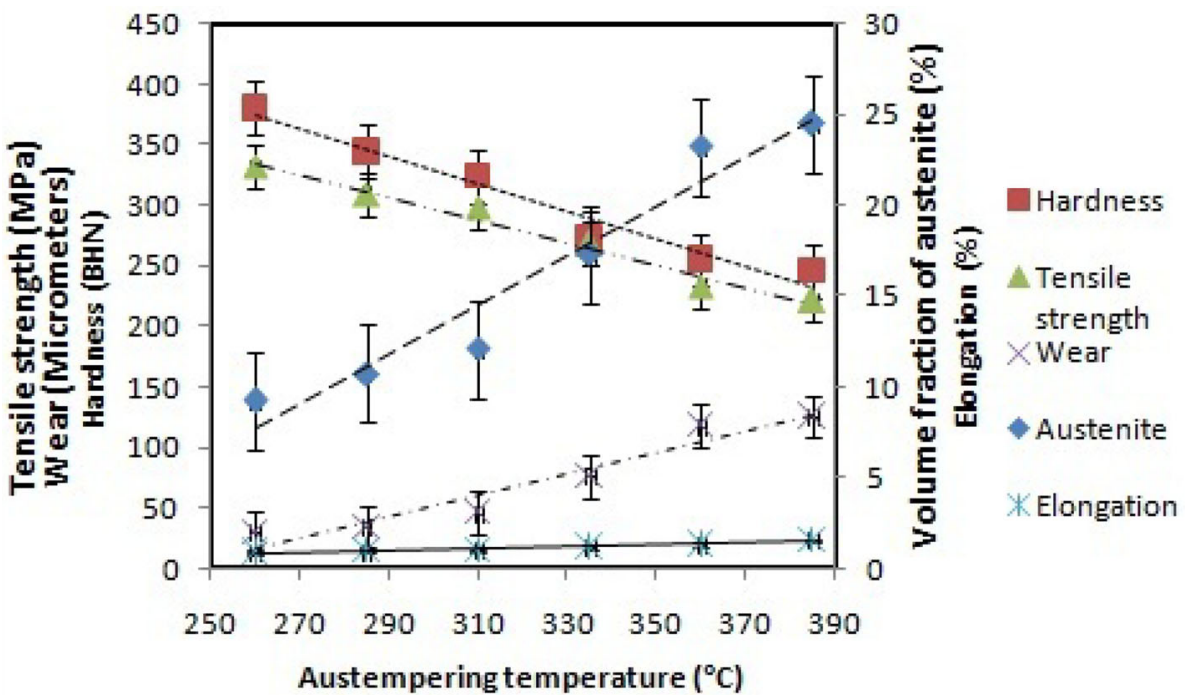

Figure 12. Influence of austempering temperature, hardness, tensile strength, elongation and austenite content on wear ( $\mu \mathrm{m})$.

temperature of $260^{\circ} \mathrm{C}$. The hardness decreased to $246 \mathrm{BHN}$ on austempering at $385^{\circ} \mathrm{C}$. The tensile strength is also found to decrease gradually as austempering temperature is increased as shown in figure 11. However, ductility measured by percent elongation is found to increase with austempering temperature (figure 11). Low austempering temperatures permitted production of high strength of AGI. On the other hand, at higher austempering temperatures, the strength of AGI is decreased. The sample austempered at $260^{\circ} \mathrm{C}$ developed a tensile strength of $332 \mathrm{MPa}$ which decreased to $221 \mathrm{MPa}$ on austempering at $385^{\circ} \mathrm{C}$. A fine ausferrite microstructure has been developed at lower temperatures has a higher hardness and tensile strength, as well as low ductility is observed. On the other hand, the coarse ausferrite microstructure that forms at a higher temperature has a lower hardness and tensile strength, while ductility increases slightly. Kovacs et al [4] and Rundman et al [5] have conducted similar investigations on AGI earlier. In the present investigation of cupola melted high phosphorus $(0.19 \%$ P) gray cast iron compared very favorably with those of the previous investigations. The high phosphorus content in the iron is not a deterrent to the development of a typical ausferrite matrix.

\subsection{Wear study}

In the present investigation, wear has occurred due to the contact between two surfaces among which one is moving surface while another is fixed surface. The moving surface 


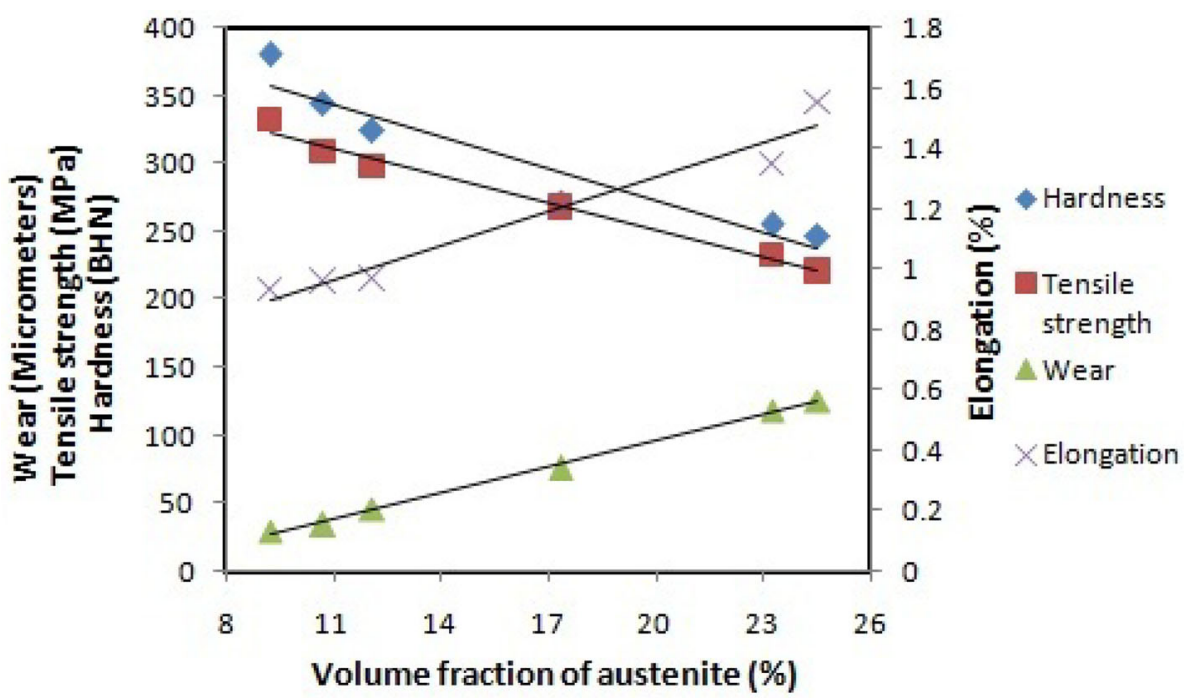

Figure 13. Influence of austenite content on hardness, tensile strength, elongation and wear $(\mu \mathrm{m})$.

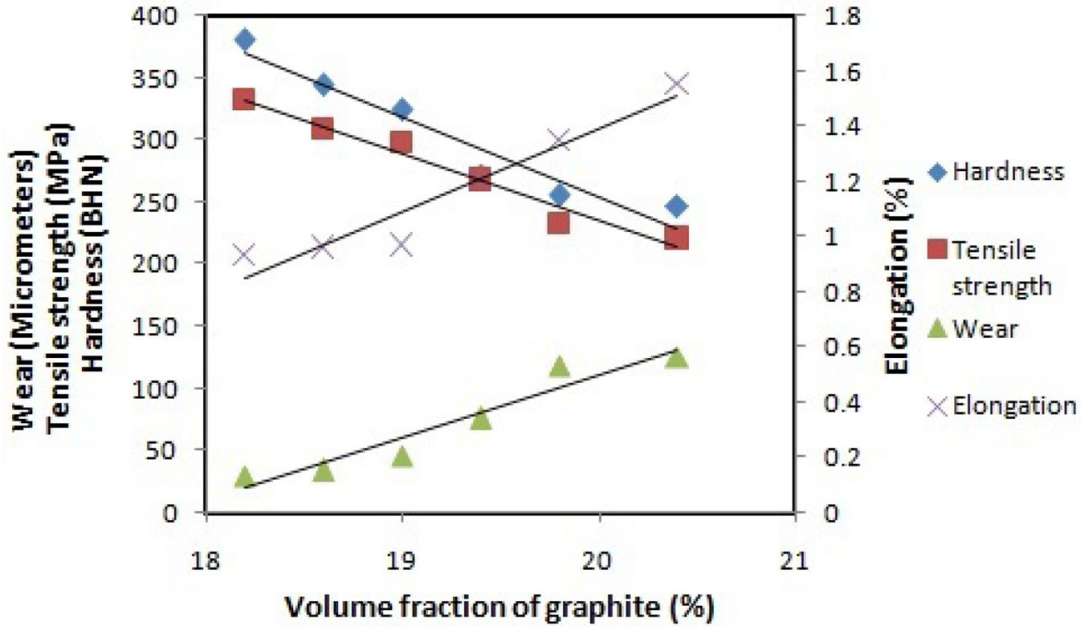

Figure 14. Influence of graphite content on hardness, tensile strength, elongation and wear $(\mu \mathrm{m})$.

is a hardened roller steel disc and the fixed one is a "block sample". The fixed block sample is pressed against the moving roller disc at a constant load.

Influence of austempering temperature, hardness, tensile strength, elongation and austenite content on the wear behavior is presented in figure 12. It is found that the samples austempering at $260^{\circ} \mathrm{C}$ have the lowest wear depth, and it increases with increasing austempering temperature. However, wear resistance decreases with the increase in austempering temperature and vice versa. At low austempering temperatures (e.g., $260-285^{\circ} \mathrm{C}$ ) fine ausferrite ferrite and austenite microstructure are formed. Such a microstructure results in high hardness and high strength, which leads to a very good wear resistance. At higher austempering temperatures (e.g., $360-385^{\circ} \mathrm{C}$ ), coarse or feathery ferrite in an ausferrite matrix is observed. The

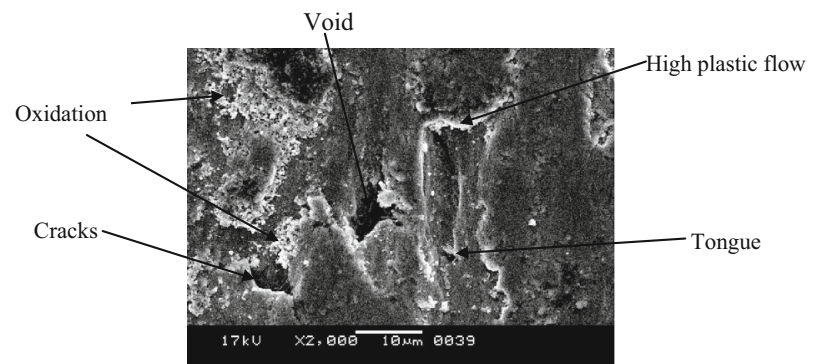

Figure 15. Worn surface of SEM micrograph of as-cast specimen.

coarser microstructures together with a large volume of austenite result in decreased hardness and tensile strength as well as wear resistance. Since there are other factors 


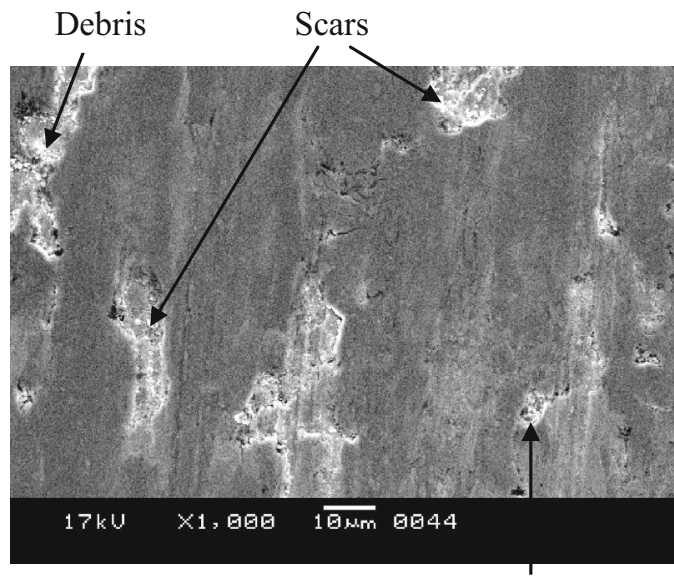

(a)

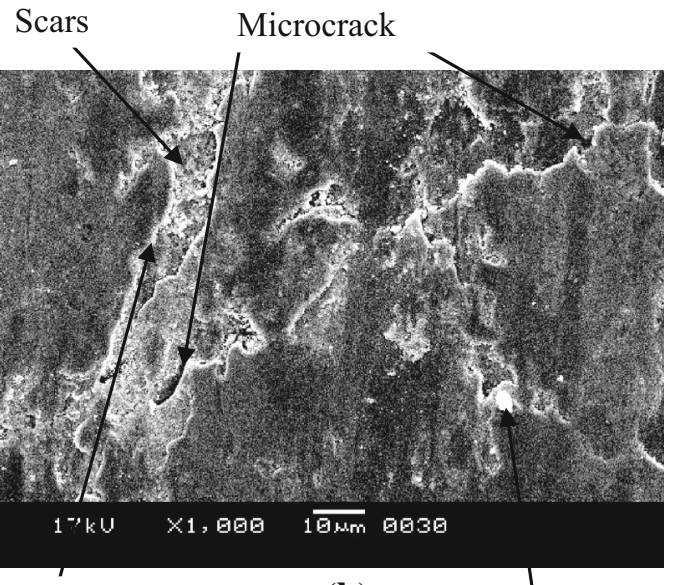

Plastic Flow (b)

Debris

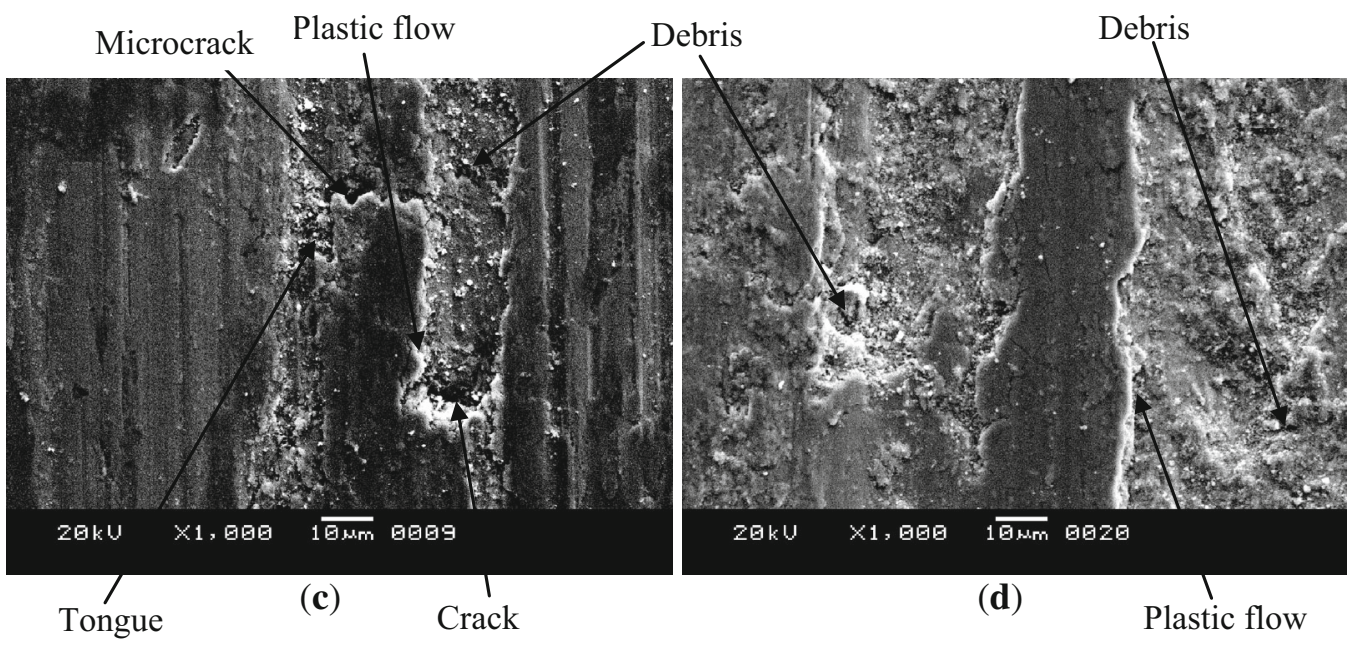

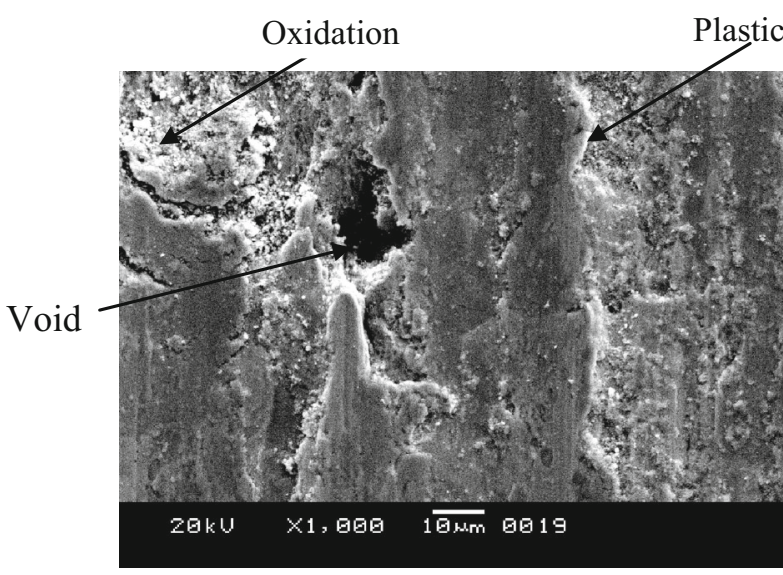

(e)

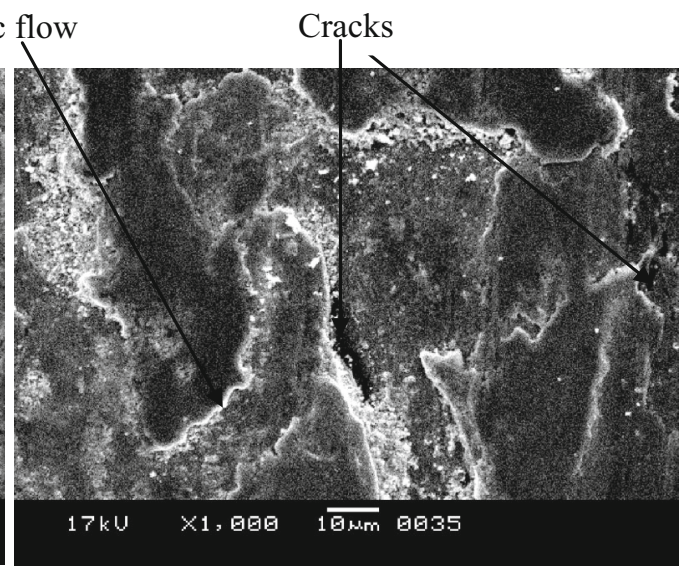

(f)

Figure 16. Worn surface of SEM micrographs of AGI samples (a) austempered at $260^{\circ} \mathrm{C}$ for $1 \mathrm{~h}$. (b) Austempered at $285^{\circ} \mathrm{C}$ for $1 \mathrm{~h}$. (c) Austempered at $310^{\circ} \mathrm{C}$ for $1 \mathrm{~h}$. (d) Austempered at $335^{\circ} \mathrm{C}$ for $1 \mathrm{~h}$. (e) Austempered at $360^{\circ} \mathrm{C}$ for $1 \mathrm{~h}$. (f) Austempered at $385^{\circ} \mathrm{C}$ for $1 \mathrm{~h}$.

responsible for improving the wear resistance even as hardness is deteriorating. The microstructural features such as the morphology, austenite content and its carbon content apparently play a crucial role in pulling down the wear resistance even as the austempering temperature is increased with the reduction in hardness. From an analysis 
of figure 12, it appears that the parameters such as hardness, tensile strength and elongation as well as the volume fraction of austenite act as independently in terms of controlling the wear resistance.

\subsection{Effect of microstructure on mechanical and wear properties}

The volume fraction of austenite present in the ausferrite matrix has a significant effect on the mechanical and wear properties of AGI. It is observed in figure 13 that the hardness and tensile strength decrease with an increasing volume fraction of austenite in the ausferrite product. However, ductility and wear depth increase with austenite content. This leads to the fact that austempering at lower temperature results in high hardness and high tensile strength as well as high wear resistance of AGI components because of the part that the ausferrite matrix contains less austenite.

In addition, figure 14 shows the effect of graphite content on mechanical properties and wear behavior of AGI. In figure 14, it is also observed that the hardness, tensile strength and wear resistance decrease with an increasing ductility and graphite content in the ausferrite product. This leads to the fact that with the increase in austempering temperature, the volume fraction of graphite increases. Accordingly, hardness, tensile strength and wear resistance decrease though ductility increases slightly.

\subsection{Worn surface}

SEM studies of the worn surfaces have been carried out to understand the nature of the wear process. The surfaces of worn specimens reveal shallow wear scars with small pits; plastic deformation of the sample surface has occurred in the direction of rotation. Voids observed on the surfaces are probably generated due to smearing of the graphite flakes from those locations. The flow of material into the pits could result in the eventual formation of wear particles. At the same time, a large quantity of metallic particles is also produced. Surface adhesion and plastic deformation mainly occurred in the underlying structure and a network of cracks had developed on the worn surface. These are signs of wear by adhesion and delamination [19].

However, figure 15 shows the worn surface of untreated gray cast iron which clearly indicates the surface of adhesion, plastic deformation, tongue and void formation due to graphite pull-out. Surface flow has occurred in the underlying structure and a network of cracks has developed. In general, the worn surfaces of austempered specimens have suffered reduced wear and deformation compared to that of the untreated gray cast iron (as cast state). Figure 16(a)-(f) show the worn surfaces of austempered specimens at different austempering temperature. The SEM images (figure 16(a)(f)) of worn surfaces of heat treated specimen show less plastic deformation in comparison with untreated gray iron. Basically, the surfaces of austempered specimens consist typically of shallow wear scars with small pits. Voids can be seen on the surfaces, probably generated at locations from which graphite flakes have been removed. Flow of material into the pits has resulted in the eventual formation of wear particles. SEM examination of the worn surfaces primarily at lower austempering temperatures of $260^{\circ} \mathrm{C}$ and $285^{\circ} \mathrm{C}$ (figure 16(a) and (b)) reveals shallow wear scars with small pits and plastic flow of wear surface. On increasing the austempering temperature (e.g., $310^{\circ} \mathrm{C}, 335^{\circ} \mathrm{C}$ ) the wear surface appearance changed markedly to show signs of scuffing, plastic flow and microcracks (figure 16(c) and (d)). With a further rise in temperature (e.g., $360^{\circ} \mathrm{C}$ and above), there is evidence of extensive plastic flow, oxidation and tongue formation as shown in figure 16(e) and (f). It is observed that with the increase in the austempering temperature, the volume fraction of austenite and graphite increases while simultaneously the wear resistance decreases.

\section{Conclusions}

Following conclusions can be drawn from the present investigation of $\mathrm{Cu}$-alloyed AGI:

1. The volume fraction of austenite and its carbon content increase with the increase in the austempering temperature.

2. The hardness and tensile strength decrease and ductility increases with the austempering temperature due to coarsen ausferrite microstructure consisting of high austenite content occurred at higher austempering temperature.

3. Wear depth increases with austempering temperature, whereas wear behavior also depends on the hardness, tensile strength as well as austenite content and carbon content in austenite.

4. The hardness, tensile strength and wear resistance decrease with increase in austenite and graphite volume while elongation increases.

\section{Acknowledgements}

The authors are thankful to the University Grants Commission (UGC) authority for providing this work under Rajiv Gandhi National Fellowship (RGNF). The authors are also grateful to Binay Udyog Pvt. Ltd, Howrah for supplying the grey iron material.

\section{References}

[1] Khanna O P 2011 Foundry technology. New Delhi: Dhanpat Rai Publications (P) Ltd, pp. 19-27 
[2] Collini L, Nicoletto G and Kone R 2007 Microstructure and mechanical properties of pearlitic gray cast iron. Mater. Sci. Eng. A 488: 529-539

[3] Xu W, Ferry M and Wang Y 2004 Influence of alloying elements on as-cast microstructure and strength of gray iron. Mater. Sci. Eng. A 390: 326-333

[4] Kovacs B V and Keough J R 1993 Physical properties and application of austempered gray iron. AFS Trans. 101: 283-291

[5] Rundman K B, Parolini J R and Moore D J 2005 Relationship between tensile properties and matrix microstructure in austempered gray iron. AFS Trans. 145(5): 1-15

[6] Hsu C H, Shy Y H, Yu Y H and Lee S C 2000 Effect of austempering heat treatment on fracture toughness of copper alloyed gray iron. Mater. Chem. Phys. 63: 75-81

[7] Olawale J O, Oluisegun K M, Ezemenaka D I and Adisa S B 2014 Production of austempered gray iron (AGI) using forced air cooling. CAMSR. 1: 17-22

[8] Brandenberg K, Hayrynen K L and Keough J R 2001 Austempered gears and shifts: Tough solutions. Gear Tech. 18: $42-50$

[9] Putatunda S K 2001 Development of austempered ductile cast iron (ADI) with simultaneous high yield strength and fracture toughness by a novel two-step austempering process. Mater. Sci. Eng. A 315: 70-80

[10] Vadiraj A, Balachandran G and Kamaraj M 2010 Structure and property studies on austempered and as-cast ausferritic gray iron. J. Mater. Eng. Perform. 19(7): 976-983
[11] Vadiraj A, Balachandran G, Kamaraj M, Gopalakrishna B and Prabhakara K 2010 Studies on mechanical and wear properties of alloyed hypereutectic gray cast irons in the as-cast pearlitic and austempered conditions. Mater. Des. 31(2): 951-955

[12] Vadiraj A, Balachandran G, Kamaraj M, Gopalakrishna B and Rao D V 2010 Structure-property correlation in austempered alloyed hypereutectic gray cast irons. Mater. Sci. Eng. A 527: 782-788

[13] Vadiraj A, Balachandran G, Kamaraj M, Gopalakrishna B and Rao D V 2010 Wear behavior of alloyed hypereutectic gray cast iron. Tribol. Int. 43: 647-653

[14] Vadiraj A, Balachandran G, Kamaraj M and Kazuya E 2011 Mechanical and wear behavior of quenched and tempered alloyed hypereutectic gray cast iron. Mater. Des. 32: 2438-2443

[15] ASTM E-8 1992 Annual Book of ASTM Standards 03(1): $545-558$

[16] Dasgupta R K, Mondal D K and Chakrabarti A K 2013 Evolution of microstructures during austempering of ductile irons alloyed with manganese and copper. Metall. Mater. Trans. A. 44A: 1376-1387

[17] Bayati H and Elliott R 1995 Austempering process in high manganese alloyed ductile cast iron. Mater. Sci. Technol. 11: $118-129$

[18] Yang J and Putatunda S K 2004 Improvement in strength and toughness of austempered ductile cast iron by a novel twostep austempering process. Mater. Des. 25: 219-230

[19] Kumari U R and Rao P P 2009 Study of wear behavior of austempered ductile iron. J. Mater. Sci. 44: 1082-1092 